\title{
Relationship between Movement of Stock Prices and Bond Prices: A Case Study of Karachi Stock Exchange
}

\begin{abstract}
Farah Mohammed
Muhammad Abdus Salam

Abstract

A potential investor may have different options for utilizing its excess ideal money but he will avail that option where he can have maximum satisfaction in terms of profitability and security. However, the higher level of uncertainty de-motivates an investor to employ his funds in a risky venture, especially during the period of economic instability. As a result, one must evaluate the factors which act as a key determinant in the market to boost up investors' confidence. KSE has been termed as high risk high premium market by researchers, so the higher persistence of volatility discourages an investor to rely on uncertain market. Instead he would be more willing in fixed income securities or may opt for diversification of its portfolio. For this purpose correlation analysis will be a helpful technique as it supports in asset allocation, portfolio selection and risk management. It identifies the degree of dependency of one portfolio on another and helps in deciding the correct proportion of allocation of funds on various assets. The two major forms of investment, stock and bonds do follow a particular pattern in the market and by analyzing their trend one can opt for a proper mix which will avert the risk associated with them. As per correlation analysis carried out on monthly data of KSE 100 and KSE all index from Nov 2003 to May 2009, it has been concluded that share indices have a positive correlation with GDP, interest rate and money supply and a negative correlation with bond prices and T-bill rates. The regression analysis of the model presented the higher value of $R$ square of $96 \%$, which represents the significance of the model.
\end{abstract}

Keywords: portfolio selection, correlation analysis, volatility.

\section{Introduction}

\subsection{Background of Study}

Finance is the key of every business and companies must generate funds for their long-term sustainability in the market. Nowadays financial markets are the key provider of funds for investments in profitable avenues by mobilizing savings from large pool of small savers to productive users of investment. Money market and capital markets are the components of financial market, where short-term needs are provided by the money markets in the form of T-bills and certificate of deposits and long-term needs are satisfied by the capital market in form of equity finance which can be raised through public or private offerings of shares and by the debt instruments in form of bonds and TFC.

Karachi Stock Exchange is the premier institution in the country to support the capital needs of the prospective investors in Pakistan. Since its inception in 1947 with a paid up capital of 37 million, it has shown tremendous growth. Today, it is owned by 200 members with a market capitalization of US $\$ 26.48$ billion and 652 listed companies shares are floating at its 1850 trading terminals. Electronic trading system has replaced the open outcry system and 4 different indices are available namely, KSE 100, KSE 30, KSE all share index and KMI index. Table 1 will give some details of KSE from 2004-2009.

\section{Table 1 Profile of Karachi Stock Exchange}

\begin{tabular}{l|c|c|c|c|c} 
& $\mathbf{2 0 0 4 - 0 5}$ & $\mathbf{2 0 0 5 - 0 6}$ & $\mathbf{2 0 0 6 - 0 7}$ & $\mathbf{2 0 0 7 - 0 8}$ & $\begin{array}{c}\mathbf{2 0 0 8}-\mathbf{0 9} \\
\text { (Jul-Mar) }\end{array}$ \\
\hline Number of Listed Companies & 659 & 658 & 658 & 652 & 652 \\
\hline New Companies Listed & 15 & 14 & 16 & 7 & 8 \\
\hline Fund Mobilized (Rs billion) & 54 & 41.4 & 49.7 & 62.9 & 42.3 \\
\hline Listed Capital (Rs billion) & 438.5 & 496 & 631.1 & 706.4 & 770.7 \\
\hline Turnover of Shares (billion) & 88.3 & 79.5 & 54 & 63.3 & 17.1 \\
\hline Average Daily Turnover of Shares (million) & 351.9 & 348.5 & 262.5 & 238.2 & 80.2 \\
\hline Aggregate Market Capitalization (Rs billion) & 2068.2 & 2801.2 & 4019.4 & 3777.7 & 2057.1 \\
\hline
\end{tabular}

Source: Economic Survey of Pakistan 2008-09, p. 91

Farah Mohammed is an MS Student at SZABIST, Karachi, farahmuhammad@yahoo.com

Muhammad Abdus Salam is Deputy Director, Statistics \& Warehouse Dept., State Bank of Pakistan, Karachi, abdussalamsbp@gmail.com 
1990 has been considered as a boom period in the history of KSE due to the reforms introduced in form of improved operational efficiency, financial liberalization, promotion of privatization culture and political stability in the economy. Later in 2002, an incredible growth in KSE 100 index and market capitalization was witnessed. Annual growth of $136 \%$ was reported over 2002-2007. The year 2008 also proved to be the promising year regardless of sub-prime crisis in the globe and by mid April 2008 KSE 100 index gained $11.6 \%$ and reached the highest level of 15676 on April 18, 2008 with a gain of 1747 pts. Later in 2008, due to worsening conditions of law and order prevailing in the country, it has fallen by $62 \%$.

Near 2009, due to timely signing of SBA with IMF and by the commitment pledges of Friends of Pakistan, it has shown a positive sign of $22.5 \%$. However, in May KSE-100 index suffered a gigantic loss of $41.6 \%$ and closed at 7177.6 pts and the magnitude of loss in USD was higher up to $52 \%$. As a result, different measures have been announced by SECP to revive the situation like changing the upper and lower circuit breakers to $10 \%$ and $1 \%$ respectively from $5 \%$ on both sides, short sale was banned in future to reduce the width of exit way to $1 / 5$ of the existing. Blank selling for deliverable future was prohibited for Oct 2008. SBP allows banks to invest up to $30 \%$ in shares, government offered 30 billion guarantee to foreign investors in put option, etc. The figure 2 will give the position of KSE from July 2008- May 2009.

Figure 1: KSE snapshot, July-May 2008-09

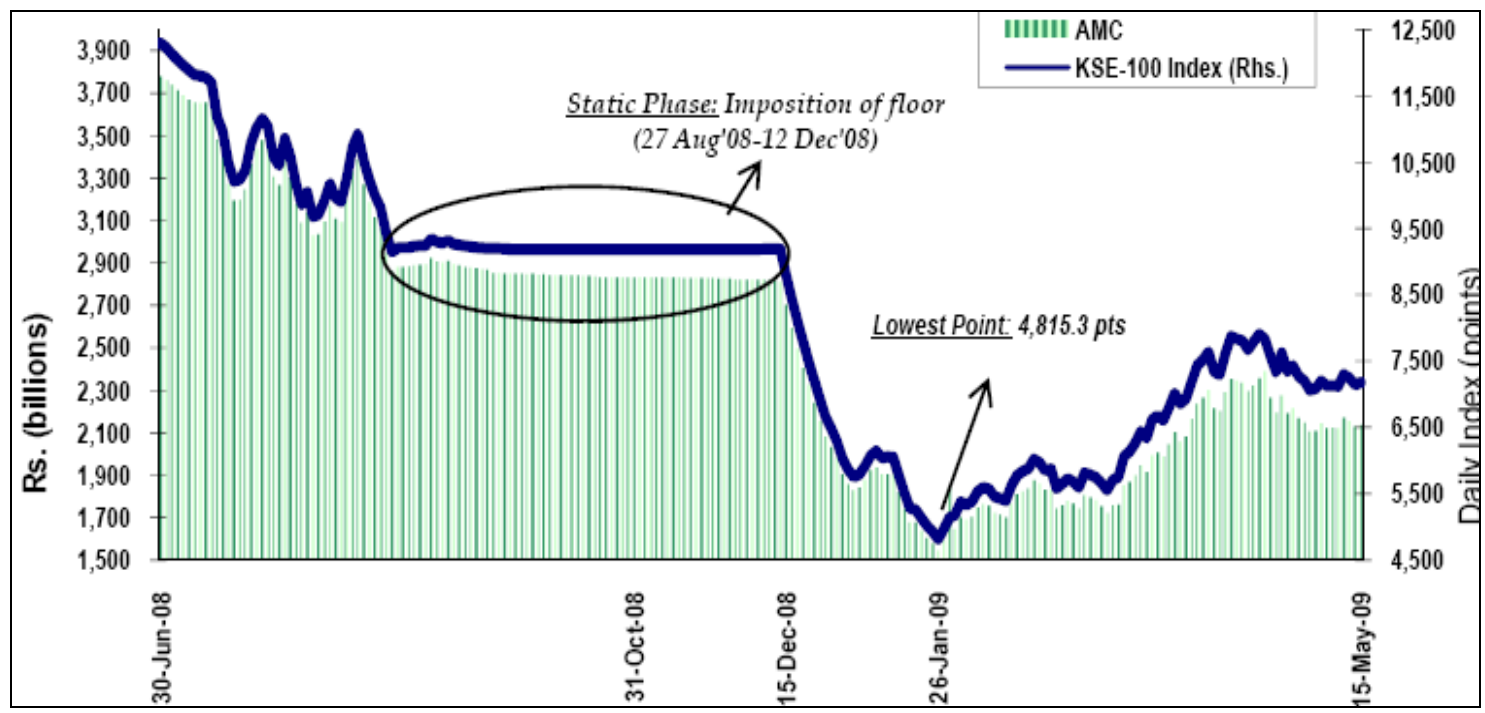

Source: Economic survey of Pakistan 2008-09, p. 89.

Debt market in Pakistan is very small in size and it offers different instruments like: government securities, national saving schemes, corporate bonds, ljara Sukuk bonds.

We need viable bond market to mobilize saving for long-term investment needs. Pakistan Investment bonds facilitate long-term government borrowings. During year 2007 and 2008, SBP raised 87.9 billion and 73.6 billion respectively from the auction of PIB's. In year 2009 and years papers have been added and rate of coupons have been revised. From July 2009-April 2009, 44.5 billion had been extracted from the auction of PIB's. Table 2 will give an overview of PIB's. 
Table 2: Overview of Pakistan Investment Bonds

\begin{tabular}{|c|c|c|c|c|c|c|}
\hline Tenor & $\begin{array}{c}2006-07 \\
\text { (Rs. billion) }\end{array}$ & $\begin{array}{l}\text { Percentage } \\
\text { Share }\end{array}$ & $\begin{array}{c}2007-08 \\
\text { (Rs. billion) }\end{array}$ & $\begin{array}{c}\text { Percentage } \\
\text { Share }\end{array}$ & $\begin{array}{c}2008-09 \\
\text { (Rs. billion) }\end{array}$ & $\begin{array}{c}\text { Percentage } \\
\text { Share }\end{array}$ \\
\hline 3-Years & 10.88 & $12.38 \%$ & 5.17 & $7.03 \%$ & 7.24 & $14.81 \%$ \\
\hline 5-Years & 10.17 & $11.58 \%$ & 10.78 & $14.65 \%$ & 5.85 & $11.97 \%$ \\
\hline 7-Years & 0.00 & $0.00 \%$ & 0.00 & $0.00 \%$ & 5.53 & $11.31 \%$ \\
\hline 10 -Years & 30.21 & $34.38 \%$ & 23.87 & $32.44 \%$ & 22.66 & $46.36 \%$ \\
\hline 15 -Years & 9.25 & $10.53 \%$ & 8.61 & $11.70 \%$ & 1.30 & $2.66 \%$ \\
\hline 20-Years & 11.25 & $12.80 \%$ & 9.05 & $12.30 \%$ & 1.70 & $3.48 \%$ \\
\hline 30 -Years & 16.10 & $18.32 \%$ & 16.10 & $21.88 \%$ & 4.60 & $9.41 \%$ \\
\hline Total & 87.86 & $\begin{array}{l}100 \% \\
\text { urce: Ecc }\end{array}$ & $\begin{array}{c}73.58 \\
\text { ic Survey }\end{array}$ & $\begin{array}{c}100 \% \\
\text { kistan } 200\end{array}$ & $\begin{array}{l}48.88 \\
\text { p. } 95 .\end{array}$ & $100 \%$ \\
\hline
\end{tabular}

ljara Sukuk is another component of Debt Market in Pakistan, which provides diversified portfolios to investors based on the principles of Islamic Financial Industry. In 2009, 27.85 billion has been raised through auction of 3 year Sukuk bonds.

NSS are the long-term government papers, which provide high yield and easy redemption facility to investors before its maturity. As of March 2009, it contributes 35\% of total domestic debt. Nowadays, it is the most attractive means of investment due to the increased in interest rates.

\subsection{Problem Statement}

Macro economic issues and instability in the political setup creates anxiety among investors and even foreign interest in equity market is declining. Due to high uncertainty in the market, investor wants to diversify their portfolios, so they can minimize the risk and maximize the returns. Now the need arises that one must evaluate the factors which govern the stock exchange in Pakistan and risk and return of market must be properly gauged in presence of other possible means of investment. Secondly one must analyze the degree of correlation which may exist between the movements of stock prices and bond prices in Pakistan.

Different researches have identified variables which may affect the stock prices. As quoted by Oseni (2009) that Al Tamini (2007) has identified some of the variables and these may include earning per share, gross domestic product, interest rates, foreign exchange rate. Higher the earnings or more the dividend a firm may declare, more people would be interested in investing their money in shares. More stable the economy would be, the more would be the growth opportunities, and hence investors may benefit from capital gains. More the interest rate, less people would be interested in shares as they may receive maximum return from banks, from government securities and bonds which are less risky in comparison to stock market.

Bond prices are also affected by different variables like: changes in economic conditions, changes in credit conditions, market psychology, budget deficit, changes in rate of inflation, changes in monetary policies i.e. interest rates, taxes, demand/supply, risk and returns (Chapman, 2002).

\subsection{Objectives of the Study}

Objective of the study would be:

- To identify the possible means of investments available in a market

- To identify the factors, which influence an investment decision regarding shares in Pakistan

- To know the degree of association between movements in share prices and bond prices.

\subsection{Benefits of the Study}

This research would be helpful for investor in identifying the investment trends prevailing in the market and will identify the key determinants of market. The findings may help investors in their decision making and they may secure their money in the most profitable and least risky option. 


\subsection{Hypotheses}

As per the essentials of financial management, we assume that the changes in stock prices may inversely affect the bond prices as when people may receive more return on bonds, they would not be willing to invest their funds in an uncertain market. The following hypotheses are generated for the research:

1. Increase in interest rates offered by banks on deposits may discourage investments in shares, as they are more secured and offers certain rates to their investors, thus creating negative impact on share price.

Our Null Hypothesis would be: $\quad \mathrm{H}_{0}=\mathrm{b}_{2}=0$

And alternate hypothesis would be: $\quad \mathrm{H}_{1}=\mathrm{b}_{2}<0$

2. More stable the economy, the more would be value of a share

Our Null Hypothesis would be: $\quad \mathrm{H}_{0}=\mathrm{b}_{4}=0$

And alternate hypothesis would be: $\quad \mathrm{H}_{1}=\mathrm{b}_{4}>0$

3. Higher the value of bonds less would be the investment in shares.

Our Null Hypothesis would be: $\quad \mathrm{H}_{0}=\mathrm{b}_{1}=0$

And alternate hypothesis would be: $\quad \mathrm{H}_{1}=\mathrm{b}_{1}<0$

4. Higher the rates offered by t-bills the less would be the value of shares.

Our Null Hypothesis would be: $\quad \mathrm{H}_{0}=\mathrm{b}_{3}=0$

And alternate hypothesis would be: $\quad \mathrm{H}_{1}=\mathrm{b}_{3}<0$

5. Greater the uncertain credit conditions the less investment would be made in shares and bonds.

Our Null Hypothesis would be: $\quad \mathrm{H}_{0}=\mathrm{b}_{5}=0$

And alternate hypothesis would be: $\quad \mathrm{H}_{1}=\mathrm{b}_{5}>0$

\subsection{Model specification}

On the basis of above hypotheses the following model will be tested.

$S_{p}=b_{o}+b_{1} P b+b_{2} R+b_{3} T b+b_{4} G d p+b_{5} M S$

Where $\mathrm{Sp}$ is the Share price

$\mathrm{Pb}$ is the price of bond

$R$ is the rate of interest offered by banks

$\mathrm{Tb}$ is the return on t-bills

Gdp is the proxy for Economic growth

MS is the money supply which is a proxy for credit conditions.

The expected signs for $b_{1}, b_{2}, b_{3}$ are negative whereas rest is positive.

\subsection{Limitations}

Due to time and data constraints only effect of above variables on share prices are evaluated.

\subsection{Research Methodology}

This research is based on empirical analysis of data from Karachi Stock Exchange and currently 4 indices are available namely KSE 100 , KSE 30 , KSE all index, KMI 30 . The research is carried out only on KSE all index and KSE 100 index. The above hypotheses are tested on monthly data of Karachi Stock Exchange of Pakistan for a period of 5 years from Nov 2003 to May 2009. The study is to be based on quantitative information collected form secondary source of data primarily from the website of Karachi Stock Exchange, and from the publications of the State Bank of Pakistan. For share prices monthly indices of KSE 100 And 
KSE all share index were taken, Bond prices figures are taken from the statistical bulletin of State bank of Pakistan, for monthly GDP the close proxy of Industrial production index was used, for interest rate weighted average deposit rates on fresh deposits are used, for t- bill rates weighted average yields are used and for money supply M2 figures are used. The statistical analysis is carried out by using the software of E-views. Different tools of testing are applied, like correlation and regression analysis, Augmented Dickey Fuller test, Ganger Causality test. Graphical analysis would be based on line graphs and histogram of all the variables.

\section{Stock and Bond Market: General Perspective}

\subsection{Concept}

Stock is an instrument of equity market which provides ownership to the investor and offers dividend as a percentage of profit, if ownership is retained otherwise investor can benefit from capital gains as prices are daily quoted in the market. It is the most risky form of investment as market is highly volatile and no fixed returns are guaranteed, even in case of liquidation of company shareholders are the last to receive their claims from the company, provided funds are available. Bonds are the instruments of debt market which offers fixed return to the investors and are least risky. In case of liquidation they are the first one to receive claims from the company.

\subsection{Factors affecting movement in Stock prices and Bond prices}

Stock prices are driven by various factors and many researches have been carried out to determine these elements playing major role in the market. Nishat and Irfan (2003) have carried out a research on how dividend policy affects stock price volatility after controlling for firm size, earning volatility, leverage and asset growth. Researcher identifies that dividend yield and payout ratios have significant but negative impact on share prices. His results have proven that size and leverage create positive and significant impact on stock prices, as highly leverage firms are more risky and the rate of change in prices would be greater whereas earning volatility has a negative and significant relation with stock prices during pre-reform period (1980-90).

In another research carried out by Nishat and Irfan (2002), key fundamental factors were identified which affect the stock prices in long run in Karachi Stock Exchange (KSE), especially after the introduction of reforms which brought more openness and competition in the market. As per the model presented by the researcher, six fundamental variables were identified namely dividend yield, payout ratio, leverage, growth, size of the firm and the earning volatility. They hypothesized that only leverage and earning volatility has a positive impact whereas the rest of the variables have negative relationship with stock prices. The results reflect that earning volatility is the most insignificant factor in KSE and even the asset growth also proves to be insignificant whereas the other four factors are not substantially significant.

The highest impact is of payout ratios, which is $16 \%$ whereas size exerts lowest but positive impact on share price. The results were consistent with emerging and developing economies where speculative forces and other macro environmental factors play more dominant role other than in developed economies where market is mainly influenced by fundamental factors. The explanatory power of these variables even varies in pre-reform (1981-90) and post reform (1991-2000) periods. In pre-reform period two fifth of the variation is explained by payout ratios, size and dividend yield and even the correct sign of the size variable is observed whereas in post reform only one third of the variation is explained by these variables leading to the conclusion that market is highly influenced by other factors, which need to be accounted.

The researcher, Al - Tamimi, Hussein (2007), examines the effect of interest rate, money supply, EPS, DPS, oil prices, GDP, consumer price index on stock prices by using the method of least square in UAE financial market. Researcher identifies that oil prices and GDP have a strong correlation, therefore he drops oil prices from his regression model. He explained this behavior by supporting data from 1990 to 2005, where on average oil prices alone constitutes 33\% share in GDP. His findings also identify strong correlation between EPS and DPS and thus he drops DPS from the model as EPS is the source of generating DPS and secondly all the companies may not pay dividend. Researcher concluded EPS as the most influencing factor which stimulates high prices for the stocks in the UAE market and companies must focus on improving EPS in order to stimulate investment in stock market.

Hussain and Mahmood (1999) evaluates the casual relationship between money supply and stock prices in Pakistan by using two measures of money supply M1 and M2 and six stock price indices (general and five 
sectoral indices based on cotton and textile, chemicals and pharmaceuticals, fuel $\mathrm{n}$ energy, transportation and communication and banks and financial institutions) for the period June 1991 to June 1999. The results prove a long run relationship between money supply and stock prices. However the error correction model does not hold a long run relation between M1 and stock prices but it do verifies one way causation from M2 to stock prices, thus giving an analysis that information about monetary assets will be helpful in determining the future prices of stock.

Mehar (2000) evaluates the effect of change in macro economic variables on market capitalization and concludes that market capitalization is caused by change in funds invested in equity and by the availability of liquidity in the market by the help of Ganger causality test. Researcher uses different exogenous variables mainly budget deficit, foreign exchange reserves, bank credits to public and private sectors, equities, external borrowing, use of cash balances, time deposits and money supply to explain the model presented by him. Results confirm that monetary and fiscal policies do affect market capitalization and equity elasticity was less than 0.55 and liquidity elasticity was greater than 1.25 .

Hussain and Mahmood (2001) evaluates the long-term casual relation between stock prices and macro variables like consumption expenditure, investment spending and economic activity in Pakistan from a period 1959-1999 and observes only unidirectional causality from macro variables to stock prices. Correlation especially improves during the reform period as reforms termed positive for the development of stock market in Pakistan. However, the researcher concludes that stock market is not fully developed in generating strong influence on macro-variables and it lags economic activity. Hussain (2006) re-examine the casual relationship between stock price and real sector variables on the basis of annual data from 1959-2005. It was reconfirmed that Pakistan's stock market is not developed enough to create a strong influence on real sector of the economy. It means reforms like economic liberalization, openness to international investors, relaxation of foreign exchange policies, privatization, etc. are still not sufficient enough to derive the prices of real sector variables.

Mustafa and Nishat (2008) evaluates the relationship between average stock trading volume and serial correlation of daily stock returns from 1991 to 2001 and identifies that stock returns are highly affected by change in fundamentals, aggregate expected returns and by changes in effective risk aversion of investors, especially during pre-nuclear test period from 1991 to 1998. However, during post nuclear period from May14 1998 to 2001, the results were insignificant. The researcher concludes that non-informational factors like structural changes in stock market, construction of stock price index based on market capitalization has a significant effect on price and trading activity and it helps in gaining confidence of the potential investors in Pakistan who requires some sort of security especially when the economy is facing political instability as well as law and order situation.

Various factors affect the prices of bond. Kluza and Slawinski (2002), evaluates the factors affecting polish bond market and confirms the relation between bond prices and expected interest rate. Changes in Polish bond prices may also have an influence on international bond prices and over the years liquidity in a market has been improved. Analysis also concludes that fluctuation of market sentiments; exchange rate volatility and budget deficits have a strong impact on bond prices in polish market.

\subsection{Correlation between the Movement of Stock Prices and Bond Prices}

Valcx (2001) has examined the factors which move US and European stock and bond markets and identifies that stock price volatility is mainly due to future return news i.e. about its dividend rate and dividend growth and also inflation news plays a significant role in both US and European stock market. In bond market, bond returns plays a significant role in US whereas in EU, bond markets rely on innovations in future bond factors. $\mathrm{Li}$ (2002) explained the correlation phenomena between stock and bond returns on the basis of macroeconomic factors and identifies that major trend in stock and bond co-movement is due to uncertainty about expected inflation. Additionally interest rate and unexpected inflation also affects the co-movement but to a lesser extent. Researcher examines the effect in all G7 countries from a period 1958-2001 and observes upward trend in stock-bond correlation until the mid 1990s.

Fang (2004) investigates the volatility between equity and bond markets of Japan and U.S by using the BEKK method and identifies that within domestic market volatility transmission is unidirectional from stock market to bond market. Lee et al (2006) analyses co-movements between bond and equity prices for different economic sectors and explores the possible determinants of equity bond co-movements and 
identifies that correlation decreases from 50\% in beginning to $40 \%$ in 2002 and later it was zero in mid 2005 . Substantial jumps have been witnessed and they largely follow the pattern of flight to quality and no significant persistence has been observed in post 2000 period. These jumps are less likely to be associated with market volatility. Long run serial dependency was noticed in post 2001 and the characteristics of early 1960's period can be used as a clue for predicting financial market position in post 2001. Chiang and Li analyses the correlation between the U.S stock and bond markets over the period 1996 to 2008 and concluded that on average the correlation between stock and bond returns is negative and time varying and depends on few macro variables like it is positively related to real income growth and the level of funds rate.

\section{Capital Markets in Pakistan}

\subsection{State of Equity Market}

Hussain and Qasim (1997) reviewed the role of Pakistan's equity market in 50 years since its inception, in strengthening the economy. Pakistan's equity market has shown great momentum in 1960 but later due to nationalization in 1970's it lose people's confidence. Later the privatization policy help in redeveloping the market and significant progress has been made in listing and market capitalization. It was ranked $3^{\text {rd }}$ in 1991 among the emerging markets, however, due to political instability and other factors, its performance was highly affected and 1995 was termed as a disaster year, as political unrest and strikes disrupted its normal functioning and it collapsed by $28 \%$ in local index and $31 \%$ in international index.

lqbal (2008) reviews the effect of liberalization and incorporation of corporate code of governance on stock market of Pakistan and compares it with other developed and emerging markets. As per the analysis of the researcher, the impact of liberalization was not positive on stock prices and economy due to non integration of market and high political instability and budget deficits. Pakistan has a very low correlation with developed markets whereas relatively larger correlation is observed with regional markets. On comparative basis, it was found that financial depth of Pakistan's equity market is lower than Indian and East Asian countries but higher than Latin America and African countries. Market size is small due to financial illiteracy and most of the people invest in land, real estate, in bank and gold reserves, even at corporate level cheap loans are available which are usually never repaid.

Trading volume has been increased due to high GDP rates, low interest rates, stable political conditions and injection of liquidity in foreign remittances by overseas Pakistanis. Return and risk on stocks are high but in comparison to other emerging markets, the difference is not too much. KSE is highly dominated by oil and gas exploration sector and stock market concentration is high in comparison to US market but developed economies have better price earning ratios. The market value on assets have shown upward trend due to increase in share prices and the incorporation of new code of governance have ensured fair trading and better allocation of resources in the market.

\subsection{Status of Bond Market}

Along with the stock, bond also holds a dominating share in a market and corporate bond market will be helpful in managing funds for long-term projects, provides competition to the banking sector which holds lion's share in corporate finance, improves allocation of capital, enhances financial stability in the economy, provides funds for investment in riskier assets where banks are reluctant to do so and is much cheaper than equity finance. Pakistan's corporate bond market is at infant stage with just one per cent share in GDP. Hameed (2006) identifies the factors which hinders the growth of corporate bond market in Pakistan like crowding out by government borrowing, administrative barriers and lack of liquidity. Researcher also presented some valuable recommendations for developing strong corporate bond market like government should regularly announce the auction of PIB's, should also borrow at market rates and reduce borrowing through national saving schemes (NSS) as it crowds out the private sector and affects the market rate for long-term funds and the rate for NSS should also be reduced.

Khalid (2007) investigates the status of domestic bond market in Pakistan and observed very slow growth in South Asian region. Researcher identifies that lack of market information and uncertain macro economic conditions decreases investor's interest in the bond market. The high level of fiscal deficits and internal and external debts has worsened the condition. Researcher proposes that regular supply of PIB's should be encouraged and proper policies should be developed for auction schedule, market pricing mechanism and yield curve. 


\subsection{Stock Market Volatility vs. Bonds}

Volatility measures the general fluctuation in asset price and as volatility increases the risk would be increased. Husain and Uppal (1999) examines the stock return volatility by using autoregressive conditional hetroscedasticity and GARCH $(1,1)$ model on daily stock prices in Pakistan from Jan 1, 1989 to Dec 30, 1993. Results prove that future prices are predictable on the basis of past volatilities. Researcher identifies that effective steps should be taken for disseminating market information to investors and presented recommendation that analytical and technical skills of the brokers or members of the market should be developed to stimulate investor's confidence and share of individuals participating in the market should be raised by providing public awareness programs.

Hameed and Ashraf (2006), evaluates the conditional volatility and test for weak form efficiency of the stock returns in Pakistani market by using the GARCH model. The results reflect the KSE -100 to be the high risk market and observes that volatility mainly declines after May 2002 due to introduction of capital market reforms by SECP which includes implementation of $T+3$ system, rationalization of risk management measurement and imposition of circuit breakers. Volatility persistence is very high which means price shocks may affect the market for a longer period of time and returns are slightly improved by the imposition of circuit breakers. 9/11 leads to massive inflow of capital in stock market and reduces volatility which was not observed widely and researcher rejects the weak form efficiency hypothesis as past information appears to be helpful in predicting future prices and also mean variance hypothesis was rejected as investors are not benefited for taking additional risk.

Bonds are less volatile than stock and offers more yield and less risk to its investors. Liquidity of the bond market improves the allocation of credit but for this purpose supply of sovereign and corporate bonds should be raised and diversification of investment products and motive is required.

\section{Empirical Analysis}

\subsection{Graphical Analysis of Dependent and Independent Variables}



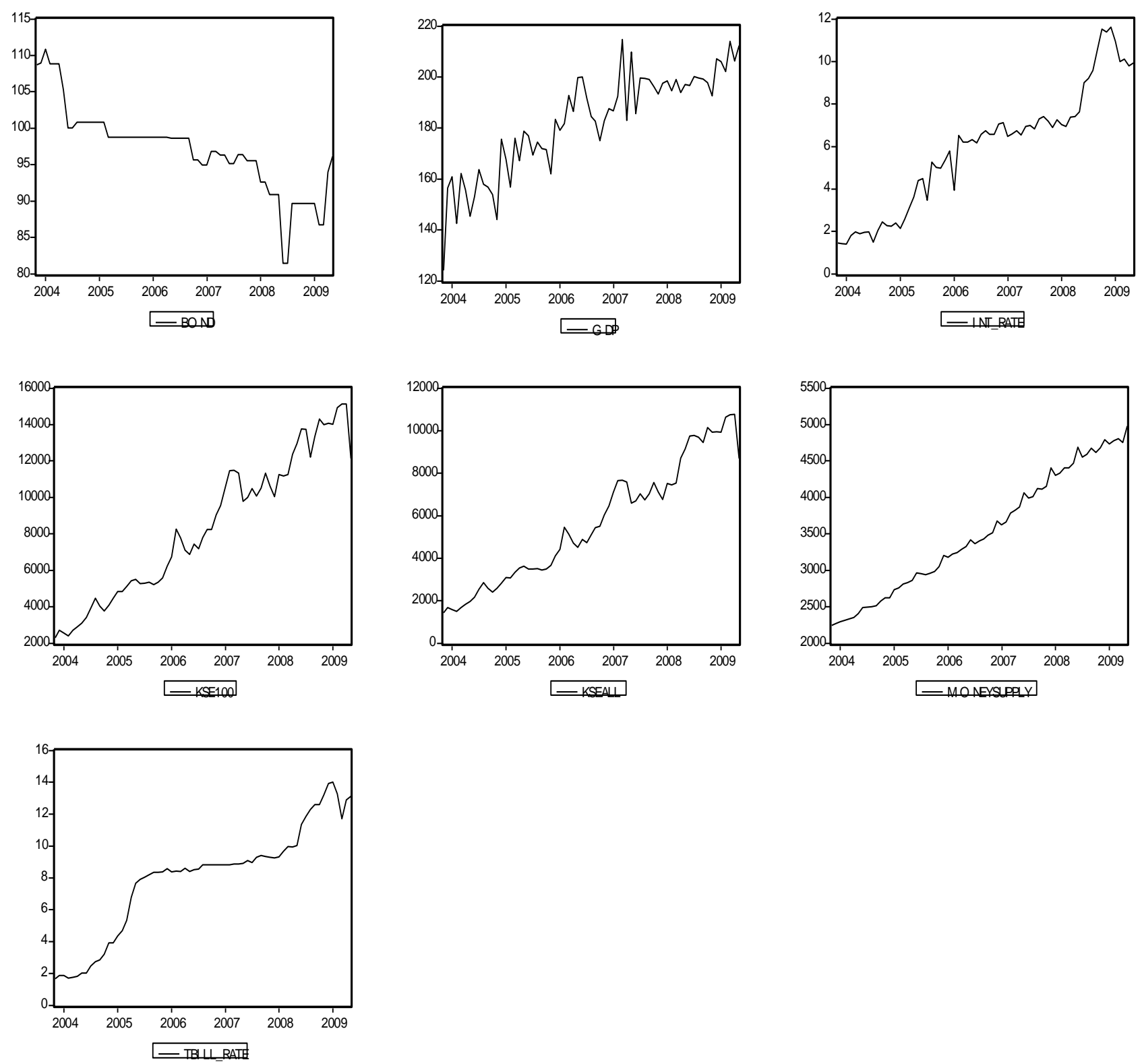

Interpretation of the Results

The plot of the data BOND, GDP, INT_RATE, KSE100, KSEALL, MONEYSUPPLY, and TBILL_RATE presents the time series data and by looking at these graphs (except for bond prices) the first impression that we get is that all variables are representing upward trend albeit with fluctuations. Only the bond prices are representing downward pattern, however, in 2009 they have shown some positive trait. The time series data shows all the variables are non-stationary. 


\subsection{Statistical analysis of hypotheses}

\section{Covarian Analysis}

\begin{tabular}{|c|c|c|r|r|r|r|r|}
\hline & BOND & GDP & INT_RATE & KSE100 & KSEALL & MONEYSUPPLY & TBILL_RATE \\
\hline BOND & 34.91698 & -88.37261 & -14.35987 & -20201.94 & -14812.54 & -4306.989 & -17.38376 \\
\hline GDP & -88.37261 & 391.5298 & 48.91116 & 66140.32 & 47683.48 & 14350.34 & 58.98668 \\
\hline INT_RATE & -14.35987 & 48.91116 & 8.197655 & 10404.79 & 7625.081 & 2254.187 & 9.479778 \\
\hline KSE100 & -20201.94 & 66140.32 & 10404.79 & 14784530 & 10774249 & 3112235. & 12013.75 \\
\hline KSEALL & -14812.54 & 47683.48 & 7625.081 & 10774249 & 7893788. & 2275615. & 8779.593 \\
\hline MONEYSUPPLY & -4306.989 & 14350.34 & 2254.187 & 3112235. & 2275615 & 687037.5 & 2626.158 \\
\hline TBILL_RATE & -17.38376 & 58.98668 & 9.479778 & 12013.75 & 8779.593 & 2626.158 & 11.80391 \\
\hline
\end{tabular}

From the above table, it is concluded that the highest value of covariance between the dependant variable KSE100 and independent variable MONEY SUPPLY is 3112235, whereas the lowest value of covariance between dependant variable KSE100 and independent variable BOND is -20201.94. The dependant variable KSE ALL also has highest covariance with independent variable MONEY SUPPLY of 2275615 and negative covariance with BOND of -14812.54 .

\section{Correlation Analysis}

\begin{tabular}{|c|c|c|c|c|c|c|c|}
\hline & BOND & GDP & INT_RATE & KSE100 & KSE ALL & MONEYSUPPLY & TBILL_RATE \\
\hline BOND & 1 & -0.7558175 & -0.848765 & -0.8891418 & -0.89221262 & -0.8793569 & -0.85627317 \\
\hline GDP & -0.7558175 & 1 & 0.863338 & 0.869321 & 0.857714744 & 0.8749629 & 0.867678 \\
\hline INT_RATE & -0.84876493 & 0.863338 & 1 & 0.9451153 & 0.94788779 & 0.9498496 & 0.963697 \\
\hline KSE100 & -0.88914183 & 0.869321 & 0.9451153 & 1 & 0.99733381 & 0.976514 & 0.909415 \\
\hline KSE ALL & -0.89221262 & 0.857715 & 0.9478878 & 0.997334 & 1 & 0.9771605 & 0.909534 \\
\hline MONEY SUPPLY & -0.879357 & 0.874963 & 0.9498496 & 0.976514 & 0.9771605 & 1 & 0.92218 \\
\hline TBILL_RATE & -0.8562732 & 0.867678 & 0.9636967 & 0.90941477 & 0.909534 & 0.922184 & 1 \\
\hline
\end{tabular}

From the above table, we can conclude that KSE 100 has a highest positive correlation of $97.65 \%$ with MONEY SUPPPLY and later $94.5 \%$ positive correlation with INT_RATE. KSE ALL has a highest positive correlation of $97.71 \%$ with MONEY SUPPLY and $(94.71 \%$ with INT_RATE. It means share indexes have a high degree of positive association with money supply and interest rate. However KSE100 has $88.9 \%$ and KSE ALL has $89.2 \%$ negative correlation with bond prices, which means that both move in opposite direction.

\section{$\underline{\text { Regression Analysis of KSE } 100 \text { Index }}$}

Dependent Variable: KSE100

Method: Least Squares

Date: 07/23/09 Time: 05:09

Sample: 2003:11 2009:05

Included observations: 67

\begin{tabular}{crlrr}
\hline \hline Variable & Coefficient & Std. Error & t-Statistic & Prob. \\
\hline \hline BOND & -105.7310 & 35.23075 & -3.001100 & 0.0039 \\
GDP & 16.29616 & 10.51619 & 1.549625 & 0.1264 \\
INT_RATE & 428.5521 & 154.2502 & 2.778291 & 0.0073 \\
MONEYSUPPLY & 3.023924 & 0.435990 & 6.935765 & 0.0000 \\
TBILL_RATE & -236.3101 & 111.2471 & -2.124191 & 0.0377 \\
$\bar{C}$ & 4328.680 & 4211.976 & 1.027708 & 0.3081 \\
\hline \hline R-squared & 0.963506 & Mean dependent var & 8335.808 \\
Adjusted R-squared & 0.960515 & S.D. dependent var & 3874.085 \\
S.E. of regression & 769.8110 & Akaike info criterion & 16.21545 \\
Sum squared resid & 36149148 & Schwarz criterion & 16.41289 \\
Log likelihood & -537.2177 & F-statistic & 322.1059 \\
Durbin-Watson stat & 1.204343 & Prob(F-statistic) & 0.000000 \\
\hline \hline
\end{tabular}


From the above table, it is concluded that the R-square and adjusted R-squared value is $96 \%$ which shows that it is a case of almost perfect regression, which means the explanatory variables are $96 \%$ efficient at predicting the variation in dependent variable. The negative coefficient of bond represents that by increase in bond prices by one unit on average may result in decline in share prices by 106 units. On the other hand, positive coefficient of interest rate explains that by one unit change in interest rate share prices would be increased by on average 429 units. The high value of F-Statistics shows the significance of the model. The probability of F-statistics is 0 . The standard error of the model is unduly large and it measures the spread of observations around the regression line. Moreover, it would be near to zero less chances of error may exist.

The independent variables i.e. INT_RATE, GDP, MONEY SUPPLY have positive relations with KSE100 but it has negative relation with TBILL_RATE and BOND. The t-statistic is significant for MONEY SUPPLY as it is higher than 1.64 (in case of one sided test) and t-bill rate and bond as it is less than -1.64 at $5 \%$ level of significance. P- Values are less than .05 for all the variables except GDP which makes quite reasonable to reject the null hypothesis. The Durbin-Watson test is a test for first-order serial correlation in the residuals of a time series regression. A value of 1.204 for the Durbin-Watson statistic indicates it has an evidence of positive serial autocorrelation as it is less than 2, which is a condition of no autocorrelation. In presence of auto correlation, OLS estimates are subject to some element of bias in small samples and yields inconsistent OLS and standard error and $t$ and $F$ test becomes invalid. In order to remove this problem we will introduce lag variables on right hand side which will make $d$ statistics invalid. The following results are reported after introducing lagged variables.

Dependent Variable: KSE100

Method: Least Squares

Date: 06/22/10 Time: 06:25

Sample(adjusted): 2003:12 2009:05

Included observations: 66 after adjusting endpoints

\begin{tabular}{lrlrr}
\hline \hline \multicolumn{1}{c}{ Variable } & Coefficient & Std. Error & t-Statistic & Prob. \\
\hline \hline C & 1022.008 & 4590.175 & 0.222651 & 0.8246 \\
BOND(-1) & -72.17994 & 38.22577 & -1.888254 & 0.0638 \\
GDP(-1) & 8.333674 & 10.50165 & 0.793558 & 0.4306 \\
MONEYSUPPLY(-1) & 3.545892 & 0.460734 & 7.696188 & 0.0000 \\
INT_RATE(-1) & 289.7146 & 156.2901 & 1.853697 & 0.0687 \\
TBILL_RATE(-1) & -152.4610 & 112.6521 & -1.353379 & 0.1810 \\
\hline \hline R-squared & 0.962977 & Mean dependent var & 8427.473 \\
Adjusted R-squared & 0.959892 & S.D. dependent var & 3829.857 \\
S.E. of regression & 767.0064 & Akaike info criterion & 16.20938 \\
Sum squared resid & 35297930 & Schwarz criterion & 16.40843 \\
Log likelihood & -528.9094 & F-statistic & 312.1234 \\
Durbin-Watson stat & 0.874146 & Prob(F-statistic) & 0.000000
\end{tabular}

After carrying out regression on lagged variables, it is concluded that by the introduction of lag variable, the $\mathrm{R}$-square and adjusted R-squared value has been slightly decreased, which once again shows that it is a case of almost perfect regression. Standard error of the regression shows slight decrease from previous value. The F-Statistics have been slightly decreased from 322 to 312, which is still highly significant. The probability of F-statistics is 0 . The independent variables i.e. INT_RATE, GDP, MONEY SUPPLY have positive relations with KSE100 but it has negative relation with TBILL_RATE and BOND. The t-statistic has been further improved for MONEY SUPPLY and still significant for bond but for the rest it is insignificant. Pvalues are less than .05 only for money supply and t-bill rate, thus we can reject the null hypothesis. 
Dependent Variable: KSE ALL

Method: Least Squares

Date: 07/23/09 Time: 05:10

Sample: 2003:11 2009:05

Included observations: 67

\begin{tabular}{crllr}
\hline \hline Variable & Coefficient & Std. Error & t-Statistic & Prob. \\
\hline \hline BOND & -80.70349 & 24.87522 & -3.244333 & 0.0019 \\
GDP & 4.072556 & 7.425120 & 0.548484 & 0.5854 \\
INT_RATE & 362.8464 & 108.9108 & 3.331594 & 0.0015 \\
MONEYSSUPPLY & 2.230374 & 0.307837 & 7.245297 & 0.0000 \\
TBILL_RATE & -183.0393 & 78.54776 & -2.330293 & 0.0231 \\
C & 4210.152 & 2973.931 & 1.415686 & 0.1620 \\
\hline \hline R-squared & 0.965926 & Mean dependent var & 5658.309 \\
Adjusted R-squared & 0.963133 & S.D. dependent var & 2830.793 \\
S.E. of regression & 543.5369 & Akaike info criterion & 15.51936 \\
Sum squared resid & 18021375 & Schwarz criterion & 15.71679 \\
Log likelihood & -513.8985 & F-statistic & 345.8405 \\
Durbin-Watson stat & 1.170346 & Prob(F-statistic) & 0.000000 \\
\hline \hline
\end{tabular}

From the above table, it is concluded that the R-square and adjusted R-squared value is $96.5 \%$ and $96.3 \%$ respectively, which is quite good enough to explain the variation in share prices. The value of F-Statistics has been further improved than KSE100, which shows the significance of the model. The probability of Fstatistics is 0 . The standard error of the regression has been improved from 770 to 544 which minimize the chances of errors. The independent variables i.e. INT_RATE, GDP, MONEYSUPPLY have positive relations with KSE100 but it has negative relation with TBILL_RATE and BOND. The t-statistic is significant for $\mathrm{t}$-bill rate and MONEY SUPPLY and even better than KSE100. Except for GDP $p$-value is smaller than .05 which ones again make it possible to reject the null hypothesis. A value of 1.17 for the Durbin-Watson statistic indicates it has an evidence of positive serial autocorrelation. Now in order to remove the autocorrelation we will include lag variables on right hand side of the regression equation. The following statistics have been reported.

Dependent Variable: KSE ALL

Method: Least Squares

Date: 06/22/10 Time: 11:26

Sample(adjusted): 2003:12 2009:05

Included observations: 66 after adjusting endpoints

\begin{tabular}{crlrr}
\hline \hline Variable & Coefficient & Std. Error & t-Statistic & Prob. \\
\hline \hline C & 4904.476 & 3091.421 & 1.586480 & 0.1179 \\
BOND(-1) & -84.77771 & 25.74454 & -3.293037 & 0.0017 \\
GDP(-1) & 0.310274 & 7.072721 & 0.043869 & 0.9652 \\
MONEYSUPPLY(-1) & 2.450852 & 0.310298 & 7.898385 & 0.0000 \\
INT_RATE(-1) & 278.6165 & 105.2593 & 2.646954 & 0.0104 \\
TBILL_RATE(-1) & -153.6396 & 75.86966 & -2.025047 & 0.0473 \\
\hline \hline R-squared & 0.968651 & Mean dependent var & 5722.411 \\
Adjusted R-squared & 0.966038 & S.D. dependent var & 2803.058 \\
S.E. of regression & 516.5685 & Akaike info criterion & 15.41880 \\
Sum squared resid & 16010580 & Schwarz criterion & 15.61786 \\
Log likelihood & -502.8204 & F-statistic & 370.7821 \\
Durbin-Watson stat & 0.906689 & Prob(F-statistic) & 0.000000 \\
\hline \hline
\end{tabular}

From the above table, it is concluded that by the introduction of lag variable the R-square and adjusted Rsquared value has shown slight improvement and is $96.9 \%$ and $96.6 \%$ respectively, which once again good 
enough to explain the variation in share prices by explanatory variables. The F-Statistics have been further improved from 346 to 371 , which show the significance of the model. The probability of F-statistics is 0 . The independent variables i.e. INT_RATE, GDP, MONEY SUPPLY have positive relations with KSE100 but it has negative relation with TBILL_RATE and BOND. The t- statistic has been further improved for MONEY SUPPLY and bond but slightly decreases for T-bill rate, however, they are still significant. P-values are less than .05 for all the variables other than GDP, thus good enough to reject the null hypothesis.

\section{ADF Analysis:}

\begin{tabular}{|l|l|l|}
\hline & LEVEL I $(0)$ & LEVEL I $(!)$ \\
\hline KSE100 & -1.11 & -4.452 \\
& $(-2.6)$ at $10 \%$ & $(-3.54)$ at $1 \%$ \\
\hline KSE ALL & -1.117 & -4.11 \\
& $(-2.6)$ at $10 \%$ & $(-3.54)$ at $1 \%$ \\
\hline BOND & -2.4 & -4.45 \\
& $(-2.6)$ at $10 \%$ & $(-3.54)$ at $1 \%$ \\
\hline MONEY SUPPLY & 0.543 & -5.296 \\
& $(-2.6)$ at $10 \%$ & $(-3.54)$ at $1 \%$ \\
\hline INT_RATE & -0.89 & -4.133 \\
& $(-2.6)$ at $10 \%$ & $(-3.54)$ at $1 \%$ \\
\hline TBILL_RATE & -1.225 & -4.03 \\
& $(-2.6)$ at $10 \%$ & $(-3.54)$ at $1 \%$ \\
\hline GDP & -0.99 & -5.87 \\
& $(-2.6)$ at $10 \%$ & $(-3.54)$ at $1 \%$ \\
\hline
\end{tabular}

On the basis of ADF test it was concluded that all the variables are not stationary at $1 \%, 5 \%$ and $10 \%$ but when ADF is carried out at first difference, all the variables become stationary at $1 \%$.

\section{Granger Causality Test:}

On the basis of Granger causality test as reported in appendix, we can have following conclusions.

1) Causal factors for GDP are KSE 100, Int_rate, Money supply, KSE ALL and t-bill rate

2) Causal factors for money supply are Bond prices and KSE100

3) Causal factors for KSE ALL are Bond prices and Money supply

4) Causal factor for KSE 100 is Money supply

5) Causal factors for Int_rate are Bond prices, T-bill rate and Money supply.

6) Causal factor for Bond prices is Money supply.

GDP does not cause any variable but it is affected by all the variables except for bond prices. Overall, the money supply is the most influencing factor explaining the variation in other variables. As economically greater supply of money in the economy means there would be more production of goods and services which may stimulate economic growth thus providing better employment opportunities which may enhance the income of people where they can invest in different sources like bonds, share market and deposits of banks may also increase.

\section{5) Conclusion}

On the basis of least square technique the following results have been derived for the model.

\section{For KSE 100 as a Dependent Variable}

Substituted Coefficients:

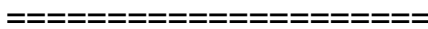

KSE100 $=1022.008293-72.17994177^{*} \mathrm{BOND}(-1)+8.333674338^{*} \mathrm{GDP}(-1)+$ 3.545891692*MONEYSUPPLY(-1) + 289.7145676*INT_RATE(-1) - 152.4609852*TBILL_RATE(-1)

Interpretation:

KSE 100 varies inversely with bond prices ( $-72 \%$ variation is explained by bond prices) 
KSE 100 varies directly with GDP ( $8.33 \%$ variation is explained by GDP)

KSE 100 varies directly with interest rate $(290 \%$ variation is explained by interest rate)

KSE 100 varies directly with money supply (3.55\% variation is explained by Money Supply)

KSE 100 varies inversely with T-bill rate (-153\% variation is explained by T-bill rate)

The sign of interest rate has been resulted contrary to the expected one.

\section{For KSE All as a Dependent Variable}

Substituted Coefficients:

$=================$

$\mathrm{KSE} A L L=4904.47636-84.77771185^{\star} \mathrm{BOND}(-1)+0.3102739859^{\star} \mathrm{GDP}(-1)+$

2.450851637*MONEYSUPPLY(-1) + 278.6164611*INT_RATE(-1) - 153.6395893*TBILL_RATE(-1)

Interpretation:

KSE ALL varies inversely with bond prices (-85\% variation is explained by bond prices)

KSE ALL varies directly with GDP $(0.31 \%$ variation is explained by GDP)

KSE ALL varies directly with interest rate $(279 \%$ variation is explained by interest rate)

KSE ALL varies directly with money supply (2.45\% variation is explained by Money supply)

KSE ALL varies inversely with T-bill rate $(-154 \%$ variation is explained by T-bill rate)

The sign of interest rate reported here, is once again contrary to the expected one but it can be justified on the mere fact that increase in interest rate may encourage savings and when people may have excessive funds they might opt for maximizing the quick, easy and huge returns on short-term basis by investing in the equity market. Overall the most stimulating factor for share investment is money supply, as concluded from correlation, regression and granger test. It has positive and direct impact on share market. If money supply decreases in an economy, it hamper economic growth, production level, investment and saving levels and thus demand for shares and bonds investment declines and vice versa. Additionally, T-bill rates also affects investment in share prices but it has an inverse impact on equity prices as they offers easier and risk free return to the investors they would be less inclined to uncertain market.

\section{6) Areas for further Research}

The effect on separate sectors should be evaluated to know the effect on separate segments of economy and other variables should be added like inflation, exchange rate, market psychology etc. 


\section{References}

Ariff, M., M. Shamsher and M. N. Annuar (1994), "Finding the factors associated with stock price volatility: a comparative study of developed and developing Share Markets.", in D. Gosh and Khaksari (eds.) Managerial finance in the Corporate Economy, London: Routledge.

Chiang, Thomas C and $\mathrm{Li}$, Jiandong (2008), "The Dynamic correlation between stock and bond returns: evidence from the U.S market", http://ssrn.com/abstract=1362225

Chapman, David (2002), "Bonds, US Dollars and Gold”, www.gold-eagle.com/research/chapmandndx.html

"Factors affecting Stock prices in the UAE financial markets (2005)", https://editorialexpress.com/cgibin/conference/download.cgi?db_name=SERC2007andpaper_id=187

Fang, V., Lim, Y.C and Lin, C.T (2004), "Volatility transmission between Stock and bond markets: evidence From Japan and the U.S", www.mssanz.org.au/modsim05/papers/fang.pdf

George E. Pinches (1996), “Essentials of financial Management”, fifth edition.

Hameed, Abid and Ashraf, Hammad (2006), "Stock Market Volatility and weak form Efficiency: Evidence from an Emerging market”, The Pakistan Development Review 45: 4 Part II, winter 2006, pg 1029-1040.

Hameed, Farhan (2006), "Fostering the corporate bond market in Pakistan", www.sbp.org.pk/research/bulletin/2007/.../Concluding-Remarks.pdf

Hussain, Fazal (2006), "Stock Prices, Real Sector and the casual Analysis: The Case of Pakistan", Journal of Management and Social Sciences, Vol: 2 pp. 179-185.

Husain, Fazal and Uppal, Jamshed (1999), "Stock Returns volatility in an Emerging Market: the Pakistani Evidence”, Pakistan Journal of Applied Economics, Vol. 15 Nos. 1and2 pp. 19-40.

Hussain, Fazal and Qasim, Muhammad Ali (1997)), "Pakistan Equity market in 50 years: A Review", Pakistan Development Review 36: 4 Part II (Winter 97), pp: 863-872.

Husain, Fazal and Mahmood, Tariq (2001), "The stock market and the Economy in Pakistan", The Pakistan Development Review 40: 2 (Summer 2001) pp. 107-114.

Husain, Fazal and Mahmood, Tariq (1999), "Monetary expansions and stock returns in Pakistan", The Pakistan Development Review 38: 4 Part II (Winter 1999) pp. 769-776.

lqbal, Javed (2008), "Stock Market in Pakistan: an overview", http://mpra.ub.unimuenchen.de/11868/1/MPRA_paper_11868.pdf

Irfan, Chaudhary Mohammad and Nishat, Mohammed (2002), "Key fundamental factors and long run price changes in an emerging market - a case study of Karachi stock Exchange (KSE)", The Pakistan Development Review 41: 4 Part II, Winter 2002, pg 1029-1040.

Oseni, Jimoh Ezekicl (2009), "Determinants of Equity prices in the stock market", http://ssrn.com/abstract=1326912

Khalid, Ahmed M (2007)," bond market developments in emerging markets: prospects and challenges for Pakistan", SBP research bulletin, Vol. 3, No. 1, 2007.

Kluza, Stainslaw and Slawinski, Andrej (2002), "Factors affecting T-bond prices: from investor's perspective", retrieved 6 June, 2009 from www.nbp.gov.pl/konferencje/falenty2002/pdf_en/skas.pdf 
Lee, Jaimee, Marsh, Terry, Maxim, Robertand Pfleiderer, Paul (2006), "Co-movements between daily returns on global bonds and Equities: A first look", www.quantal.com/papers/JOIMPaper_Text_Mar13.pdf

$\mathrm{Li}$, Ling Feng (2002), "Macroeconomic factors and the Correlation of Stock and Bond returns", http://papers.ssrn.com/so13/papers.cfm?abstractid=36341

Mehar, Ayub (2000), "Stock market consequences of macro economic fundamentals", http://mpra.ub.unimuenchen.de/442/MPRA Paper NO. 442.

Mustafa, Khalid and Nisha (no date), Mohammed "Trading Volume and serial correlation in stock returns in Pakistan", www.pide.org.pk/pdf/psde\%2018AGM/Trading\%20Volume.pdf

Nishat, Dr. Mohammed and Irfan, Chaudhary Mohammad (2003), "Dividend Policy and stock price volatility in Pakistan", www.pide.org.pk/.../DIVIDEND\%20POLICY\%20AND\%20STOCK\%20PRICE\%20VOL

Pakistan Government of (2009) Economic Survey 2008-9, Islamabad.

State Bank of Pakistan (2009) Publication, Karachi.

State Bank of Pakistan (2009) Statistical Bulletin, Karachi

Valckx, Nico (2001), "Factors affecting asset price expectations: fundamentals and policy variables", http://papers.ssrn.com/sol3/papers.cfm?abstract_id=317922 


\section{Appendix \\ GRANGER CAUSALITY TEST}

Pairwise Granger Causality Tests

Date: 07/23/09 Time: 06:00

Sample: 2003:11 2009:05

Lags: 2

\begin{tabular}{|c|c|c|c|}
\hline Null Hypothesis: & Obs & F-Statistic & Probability \\
\hline $\begin{array}{l}\text { GDP does not Granger Cause BOND } \\
\text { BOND does not Granger Cause GDP }\end{array}$ & 65 & $\begin{array}{l}1.82923 \\
3.05563\end{array}$ & $\begin{array}{l}0.16938 \\
0.05448\end{array}$ \\
\hline $\begin{array}{l}\text { INT_RATE does not Granger Cause BOND } \\
\text { BOND does not Granger Cause INT_RATE }\end{array}$ & 65 & $\begin{array}{l}1.37314 \\
3.94246\end{array}$ & $\begin{array}{l}0.26116 \\
0.02462\end{array}$ \\
\hline $\begin{array}{l}\text { KSE100 does not Granger Cause BOND } \\
\text { BOND does not Granger Cause KSE100 }\end{array}$ & 65 & $\begin{array}{l}2.07194 \\
1.75801\end{array}$ & $\begin{array}{l}0.13486 \\
0.18115\end{array}$ \\
\hline $\begin{array}{l}\text { KSEALL does not Granger Cause BOND } \\
\text { BOND does not Granger Cause KSEALL }\end{array}$ & 65 & $\begin{array}{l}2.09209 \\
5.34886\end{array}$ & $\begin{array}{l}0.13234 \\
0.00728\end{array}$ \\
\hline $\begin{array}{l}\text { MONEYSUPPLY does not Granger Cause } \\
\text { BOND } \\
\text { BOND does not Granger Cause MONEYSUPPLY }\end{array}$ & 65 & $\begin{array}{l}5.77515 \\
4.13330\end{array}$ & $\begin{array}{l}0.00508 \\
0.02081\end{array}$ \\
\hline $\begin{array}{l}\text { TBILL_RATE does not Granger Cause BOND } \\
\text { BOND does not Granger Cause TBILL_RATE }\end{array}$ & 65 & $\begin{array}{l}2.41923 \\
5.34403\end{array}$ & $\begin{array}{l}0.09762 \\
0.00731\end{array}$ \\
\hline $\begin{array}{l}\text { INT_RATE does not Granger Cause GDP } \\
\text { GDP does not Granger Cause INT_RATE }\end{array}$ & 65 & $\begin{array}{l}4.86539 \\
2.76673\end{array}$ & $\begin{array}{l}0.01101 \\
0.07090\end{array}$ \\
\hline $\begin{array}{l}\text { KSE100 does not Granger Cause GDP } \\
\text { GDP does not Granger Cause KSE100 }\end{array}$ & 65 & $\begin{array}{l}7.37481 \\
0.28036\end{array}$ & $\begin{array}{l}0.00137 \\
0.75650\end{array}$ \\
\hline $\begin{array}{l}\text { KSEALL does not Granger Cause GDP } \\
\text { GDP does not Granger Cause KSEALL }\end{array}$ & 65 & $\begin{array}{l}6.32117 \\
0.31711\end{array}$ & $\begin{array}{l}0.00323 \\
0.72946\end{array}$ \\
\hline $\begin{array}{l}\text { MONEYSUPPLY does not Granger Cause GDP } \\
\text { GDP does not Granger Cause MONEYSUPPLY }\end{array}$ & 65 & $\begin{array}{l}5.34712 \\
0.08473\end{array}$ & $\begin{array}{l}0.00729 \\
0.91887\end{array}$ \\
\hline $\begin{array}{l}\text { TBILL_RATE does not Granger Cause GDP } \\
\text { GDP does not Granger Cause TBILL_RATE }\end{array}$ & 65 & $\begin{array}{l}5.45615 \\
0.86477\end{array}$ & $\begin{array}{l}0.00665 \\
0.42633\end{array}$ \\
\hline $\begin{array}{l}\text { KSE100 does not Granger Cause INT_RATE } \\
\text { INT_RATE does not Granger Cause KSE100 }\end{array}$ & 65 & $\begin{array}{l}1.67217 \\
2.02537\end{array}$ & $\begin{array}{l}0.19647 \\
0.14087\end{array}$ \\
\hline $\begin{array}{l}\text { KSEALL does not Granger Cause INT_RATE } \\
\text { INT_RATE does not Granger Cause KSEALL }\end{array}$ & 65 & $\begin{array}{l}2.61864 \\
1.62007\end{array}$ & $\begin{array}{l}0.08122 \\
0.20642\end{array}$ \\
\hline
\end{tabular}

$=$ 


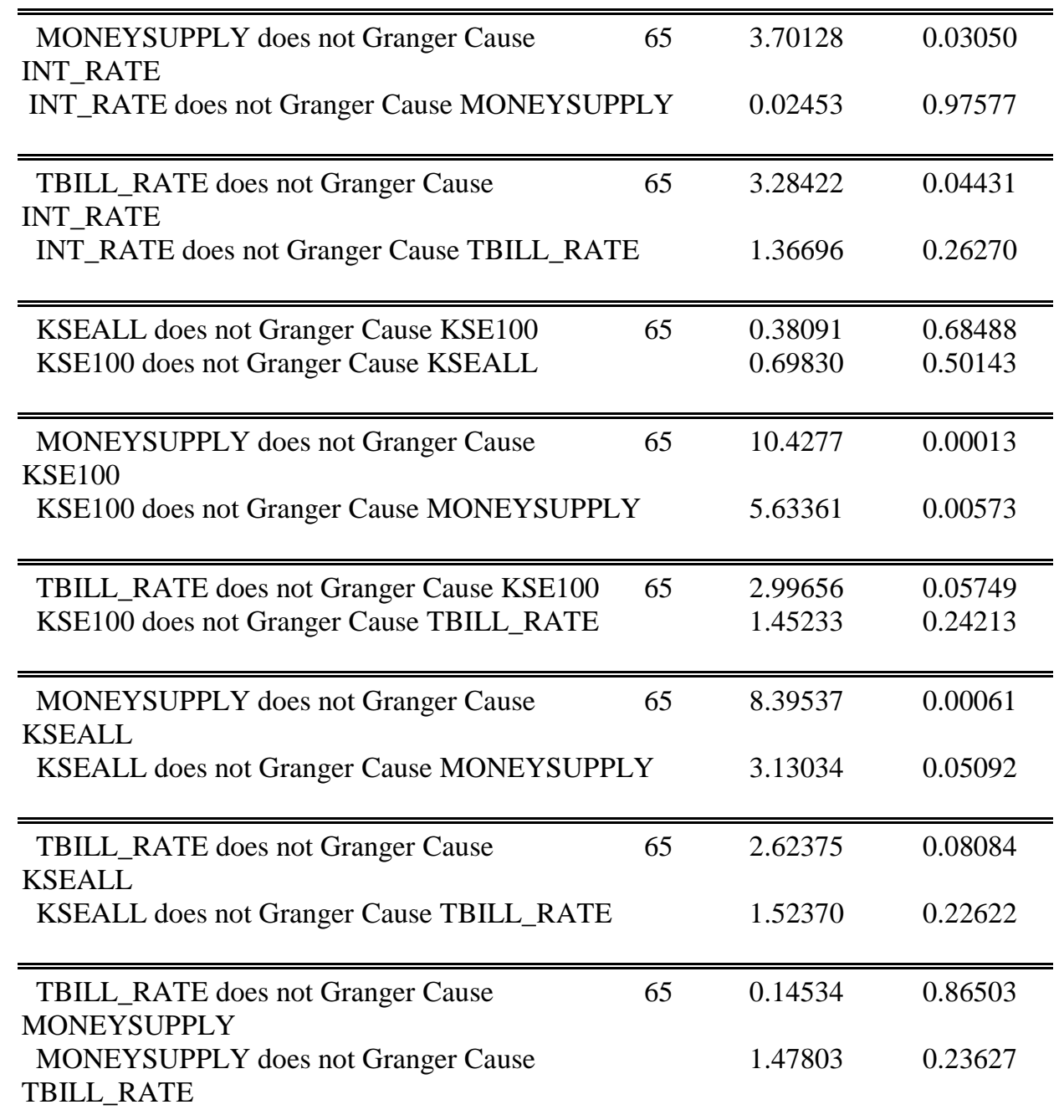

